\title{
A QUESTÃO JUDAICA NAS ORIGENS DA FILOSOFIA POLÍTICA DE HANNAH ARENDT
}

\author{
Kherlley Caxias Barbosa ${ }^{1}$
}

\begin{abstract}
RESUMO
A guinada de Arendt para a política tem início com sua adesão à luta pela emancipação judaica. Suas primeiras reflexões políticas tratam da questão judaica. Arendt defende o direito político do judeu de viver como judeu sem abrir mão de suas tradições e modo de vida contra as ideologias do antissemitismo e do assimilacionismo, mas critica a postura antipolítica dos judeus que se negaram historicamente, com algumas exceções, a se engajar na ação política.
\end{abstract}

PALAVRAS-CHAVE: Questão judaica. Emancipação. Antissemitismo. Ação. Filosofia Política.

\begin{abstract}
Arendt's turn to the politics has begun when she joined to the fight for Jewish emancipation. Her first political reflections deal with the Jewish Question. Arendt defends the political right to a Jew lives as a Jew without living traditions and way of life behind. This defense is made against the ideologies of anti-semitism and assimilationism. She criticizes the anti-political stance of Jews who have historically refused, with some exceptions, to engage into political action.
\end{abstract}

KEY-WORDS: Jewish Question. Emancipation. Anti-semitism. Action. Arendt. Political Philosophy.

\section{Introdução}

Nesse estudo ${ }^{2}$ trato das origens do pensamento político de Arendt, que começa com a guinada para a política desde seu envolvimento com o sionismo, quando deixou a "torre de marfim" da filosofia centrada na atividade contemplativa para inserir-se no mundo dos assuntos humanos. Em seguida à apresentação dessa experiência de engajamento político, assinalo como Arendt fez suas primeiras tentativas de compreensão política ao refletir sobre a questão judaica, considerando um conjunto de textos ${ }^{3}$ que

\footnotetext{
${ }^{1}$ Bacharel e Mestre em Teologia pela Faculdade San Bonaventura/Seraphicum (Itália). Licenciado em Filosofia pela Universidade Católica de Goiás. Doutor em Filosofia pela Universidade do Vale do Rio dos Sinos/Unisinos. Professor do Curso de Filosofia da Universidade Federal do Tocantins.

${ }^{2}$ As citações das obras de Arendt utilizadas neste trabalho referem-se, primeiramente, ao original em inglês e, em seguida, à tradução em português. Quando não aparecer a citação de ambas significa que está sendo citada apenas a versão em inglês, com tradução nossa.

${ }^{3}$ The Jewish Writings é uma coletânea dos textos judaicos de Arendt, publicada em 2007, que reúne num só volume textos previamente publicados e também inéditos. Na exposição dou destaque aos textos inéditos, mas faço referência, quando necessário, àqueles publicados anteriormente na coletânea The Jew as a Pariah, de 1978.
} 
concentram suas primeiras reflexões políticas, depois passo a explanar a interpretação política que Arendt dá ao fenômeno do antissemitismo, e findo essa análise tratando das reflexões originárias sobre o tema central da sua filosofia política: a ação.

A filosofia política desenvolvida por Arendt parte de uma problemática política que também é pessoal para ela: a questão judaica. A questão judaica desencadeia o início do pensamento político de Arendt; como diz Bernstein, "é o agente catalisador da cristalização do seu pensamento". ${ }^{4}$

Arendt se entrega à atividade de pensar a questão judaica a partir da sua experiência de ser judia. O seu envolvimento com essa questão é tanto prático quanto teórico uma vez que assume uma postura de responsabilidade frente aos ataques sofridos pelo seu povo, ao mesmo tempo que busca compreender filosoficamente a própria questão. ${ }^{5}$ Do ponto de vista teórico, sua posição consiste na defesa da liberdade dos judeus por meio de uma emancipação política que possibilite o exercício da liberdade e do direito dos judeus viverem como judeus. Essa posição critica a solução da questão judaica por meio da assimilação social que implica na perda da identidade cultural e da tradição histórica do povo judeu.

\section{A guinada política de Arendt}

Arendt dá seus primeiros passos rumo à política em virtude de sua condição de ser judia de nascença. ${ }^{6}$ Desde cedo tomou consciência dessa condição e do modo de defender-se por causa desse fato incontornável que marca sua existência. Um judeu tem o direito de viver segundo sua condição judaica, por isso, quando atacado, deve se

\footnotetext{
${ }^{4}$ É representativa a posição de Richard Bernstein a respeito, "abordar Arendt do ponto de vista de sua compreensão e de sua resposta à questão Judaica e às formas políticas de antissemitismo que surgiram nos séculos XIX e XX é para usar sua própria linguagem uma perspectiva essencial para alcançar uma compreensão dos principais temas do seu pensamento. Para usar uma de suas metáforas favoritas, nós podemos afirmar que seu enfrentamento da questão Judaica foi o agente catalisador para cristalizar seu pensamento". (BERNSTEIN, 1996, p. 9).

${ }^{5}$ A "questão judaica" é um fenômeno complexo cuja base real é o fato de que os judeus após a Diáspora se dispersaram pelo mundo passando a viver num território ocupado por povos de diferentes costumes e tradições, onde desenvolveram suas atividades econômicas e culturais e, em geral, submeteram-se aos governantes locais. A questão judaica é analisada por Arendt mais no seu aspecto político do que nos aspectos religioso e social, embora faça referência também a essas dimensões da questão.

${ }^{6}$ Jerome Kohn, no Prefácio à The Jewish Writings (p. xi), sustenta que Arendt atualiza (actualize) na política o dado (givenness) existencial de ser judia. Numa polêmica com Gershon Scholem, Arendt expressa sua gratidão por nascer judia: "Ser uma judia pertence para mim aos fatos indisputáveis da minha vida, e eu nunca tive o desejo de mudar ou renunciar a fatos deste tipo. Existe uma coisa tal como uma atitude básica por tudo que é como é; por aquilo que foi dado e não feito; por aquilo que é physei e não nomoi". (KOHN, 2007, p. 466).
} 
defender como judeu, isto é, como membro de um povo com identidade cultural singular, e não como uma entidade abstrata. ${ }^{7}$

Arendt conta ${ }^{8}$ que quando os nazistas começaram a perseguição contra os judeus, sentiu-se responsável e passou a agir em favor de seu povo. ${ }^{9}$ De maneira que as razões de sua guinada para a política estão estribadas na sua experiência pessoal de judia, tanto pela afirmação de sua identidade cultural quanto pela sua solidariedade prática com a causa política do seu povo.

Em 1933, após colaborar com o movimento sionista ${ }^{10}$ Arendt foi presa. Depois do relaxamento da sua prisão, ela e sua mãe deixam a Alemanha rumo a França ${ }^{11}$, de onde seguem, após anos de refúgio, para os Estados Unidos da América, no ano de 1941. ${ }^{12}$

Durante os anos da guerra, Arendt continuou refletindo sobre a questão judaica e defendendo posições firmes a respeito dos judeus, seja advogando pela criação de um exército judaico ${ }^{13}$ seja defendendo a criação de um Estado binacional como forma de resolução da questão árabe-judaica. ${ }^{14}$

\footnotetext{
7 "Se alguém é atacado como judeu, tem se defender como judeu. Não como alemão, não como cidadão do mundo, não como defensor de Direitos do Homem ou seja o que for". (ARENDT, 1994, p. 12/41).

${ }^{8}$ O relato aparece numa entrevista transmitida para a televisão alemã, realizada em 1964, e publicada em 1994, com o título "O que resta? A língua resta: uma conversa com Günter Gaus", na coletânea de ensaios Essays in Understanding. Cf. ARENDT, 1994, p. 1-23/31-53.

9 “Gaus: Há algum fato definido em sua memória marcando sua guinada para o político? Arendt: Eu diria 27 de fevereiro de 1933, o incêndio do Reichstag e as prisões ilegais que se seguiram na mesma noite. A chamada prisão preventiva. Como você sabe, as pessoas foram levadas para porões da Gestapo ou para campos de concentração. O que aconteceu então foi monstruoso, mas agora ficou obscurecido por coisas que vieram depois. Foi um choque imediato para mim, e daquele momento em diante me senti responsável. Isto é, não achava mais que se pudesse ser um simples expectador. Tentei ajudar de muitas maneiras". (ARENDT, 1994, p. 4-5/35).

${ }^{10}$ Arendt não era uma sionista, embora tenha sido influenciada pelo movimento, como ela mesma diz a Gaus: "Eu tinha amizade intima com alguns dos líderes, principalmente com o presidente da época, Kurt Blumenfeld. Mas eu não era sionista. Mas, em certo sentido, eu era influenciada por eles: em especial pela crítica, pela autocrítica que os sionistas difundiam entre o povo judeu". (ARENDT, 1994, p. 5/35). Arendt confessou a Jaspers que considerava entediante a questão judaica até conhecer Kurt Blumenfeld, "a pessoa que abriu meus olhos nesta área". (ARENDT, 1992, p. 97).

${ }^{11}$ Em Paris, conseguiu trabalho numa organização judaica que levava jovens judeus da Alemanha para a Palestina e na Agência Judaica que ajudava refugiados em Paris. Quando a guerra eclodiu, Arendt foi levada para o campo de internamento de Gunz, de onde conseguiu escapar.

${ }_{12}$ Nos Estados Unidos da América, Arendt continuou engajada politicamente nos assuntos judaicos. Publicava seus artigos no Aufbau, "um semanário vigoroso que se destinava a refugiados de idioma alemão em todo o mundo e proporcionava aos intelectuais alemães um fórum para as suas visões políticas". (YOUNG-BRUEHL, 1997, p. 169).

${ }^{13}$ Cf. o artigo "O exército judaico - o início da política judaica" de 1941, que foi republicado em Jewish Writtings, juntamente com outros artigos do mesmo período numa seção intitulada "The Jewish War that isn’t happening”: Aufbau, October 1941 - November 1942. (Cf. ARENDT, 2007, p. 134ss).

14 "Uma federação genuína é feita por diferentes nacionalidades, claramente identificáveis ou outros elementos que juntos formam um estado. Conflitos nacionais podem ser resolvidos dentro de tal federação somente porque o insolúvel problema maioria-minoria cessou de existir". (ARENDT, 2007, p. 195). Segundo sua biógrafa, a posição de Arendt contrapunha-se à dos nacionalistas judeus que "identificavam o estado com o grupo nacional que receberia o status de maioria". (YOUNG-BRUEHL, 1997, p.180).
} 
Uma consequência imediata da guinada de Arendt para a política foi a sua reavaliação da filosofia. Com a experiência do engajamento político judaico e do posicionamento dos filósofos frente aos eventos políticos desencadeados pelos nazistas, Arendt descobriu uma tensão entre a filosofia e a política. Essa tensão perpassará toda a sua filosofia política. Ao rememorar a postura dos intelectuais com a ascensão do nazismo, descreveu o sentimento que a abateu então:

E entre os intelectuais a Gleichschaltung era a regra, por assim dizer. ... E nunca esqueci isso. Saí da Alemanha dominada pela ideia, claro que um pouco exagerada: Nunca mais! Nunca mais vou me envolver em nenhum tipo de atividade intelectual. Não quero ter nada a ver com aquilo... Eu achava que tinha a ver com essa profissão, com o fato de ser um intelectual. (ARENDT, 1994, p.10-11/41; grifo nosso)

A recusa de Arendt em ser chamada de filósofa é compreensível à luz da experiência que teve da postura política dos intelectuais alemães. ${ }^{15} \mathrm{O}$ que é importante salientar é que a tensão fundamental entre a filosófico e o político se funda num conflito entre as atividades humanas, entre o pensar e o agir ${ }^{16}$, entre as atividades que definem o estilo de vida dos homens de ação e dos homens de contemplação:

Sempre digo que existe uma tensão vital entre filosofia e política. Isto é, entre o homem como ser que pensa (thinking being) e o homem como ser que age (acting being). Há uma tensão que não existe na filosofia natural, por exemplo. Como todo mundo, o filósofo pode ser objetivo em relação à natureza e quando diz o que pensa sobre ela, fala em nome de toda a humanidade. Mas ele não pode ser objetivo ou neutro em relação à política. Não desde Platão! .... Há uma espécie de inimizade a toda a política na maioria dos filósofos ... eu não quero ter parte nesta inimizade. (ARENDT, 1994, p. 2/31; tradução modificada).

Por ter tido a experiência do olhar turvo da filosofia e do comportamento ‘deformado' dos filósofos em relação à política, Arendt procurou, desde o início,

\footnotetext{
${ }^{15}$ Arendt expressa na entrevista dada a Gauss: "Não pertenço ao círculo dos filósofos. Minha profissão, se é que se pode chamar assim, é a teoria política. Não me sinto uma filósofa, nem creio ter sido aceita no círculo dos filósofos. Em minha opinião, eu me despedi da filosofia de uma vez por todas. Como você sabe, estudei filosofia, mas isso não significa que continuei com ela". (ARENDT, 1994, p. 1/31-32).

${ }^{16}$ A respeito da tensão entre as atividades do pensar e do agir, Arendt admite, num congresso sobre a sua filosofia política em 1972, ser menos propensa para a atividade de agir do que para a atividade do pensar. "Eu admitirei que sou principalmente interessada em compreender. Isto é absolutamente verdadeiro. E eu admitirei que há outras pessoas que são principalmente interessadas em fazer alguma coisa. Eu não. Eu posso muito bem viver sem fazer nada. Mas eu não posso viver sem tentar pelo menos compreender o que acontece". (ARENDT, 1979 p. 303).
} 
desvencilhar-se da postura tradicional da filosofia em relação à política. Essa atitude tornou-se basilar para construir um pensamento diferente dos moldes da tradição da filosofia política. "Eu quero olhar para a política, por assim dizer, com os olhos não toldados pela filosofia" (ARENDT, 1994, p. 2/32).

Seja qual for a designação dada por ela ao seu trabalho intelectual, Arendt nos seus escritos, admitindo ou não ser uma filósofa, pensou a política partindo de questões filosóficas, ${ }^{17}$ e por essa razão que não reputo descabido o uso da expressão 'filosofia política' para definir seu pensamento político.

O turn para a política, no duplo sentido de engajamento prático e de passagem da teoria filosófica para a análise política, está na origem da filosofia política de Arendt que versa primeiramente sobre a questão judaica e o antissemitismo, que passo a tratar em seguida.

\section{A questão judaica em The Jewish Writings}

A posição de Arendt sobre a questão judaica parte de uma crítica às respostas dadas a essa problemática, sobretudo à proposta de assimilacionismo que implica a destruição da identidade da diferença cultural judaica. Arendt defende a emancipação dos judeus por entender que têm direito à liberdade de viver como judeus na afirmação de sua diferença cultural. Além disso, busca elucidar as origens do antissemitismo político.

\section{A defesa da emancipação judaica}

\footnotetext{
${ }^{17} \mathrm{Em}$ A Vida do Espírito, Arendt revela sua inquietação por ter de tratar de questões tipicamente filosóficas como a atividades do pensar, do julgar e do querer: "O que me perturba é que seja $e u$ a tentar, pois não pretendo nem ambiciono ser uma "filósofa", ou estar incluída entre aqueles que Kant não sem ironia chamou de Denker von Gewerbe (pensadores profissionais). A questão, pois, é se eu não deveria ter deixado tais problemas nas mãos dos especialistas. E assim sendo, a resposta deverá mostrar o que me levou a abandonar o âmbito relativamente seguro da ciência e da teoria política para me aventurar nesses temas espantosos, ao invés de deixá-los em paz". (ARENDT, 1978, p. 3/5).
} 
Num texto pioneiro ${ }^{18}$, Arendt analisa a questão judaica ${ }^{19}$ no contexto do Iluminismo ${ }^{20}$, confrontando duas posições diferentes - a do ilustrado judeu Moses Mendelssohn e a do romântico Herder. Ambas posições são criticadas por ela porque, apesar de partir de pontos de vista distintos, comungam de um mesmo pressuposto: o reconhecimento da igualdade dos judeus tem que ser pago pelo preço da perda da identidade judaica, por meio da assimilação social.

A posição de Mendelssohn ${ }^{21}$ baseia-se na autonomia da razão frente à religião e à história. Na visão de Mendelssohn, a religião judaica não é demolida pela crítica da razão, pois a base que sustenta o judaísmo são as "verdades eternas", conhecidas pela razão, e não o texto sagrado das escrituras. ${ }^{22}$ Arendt percebe a implicação política da posição de Mendelssohn: a condição para a inclusão dos judeus na humanidade ilustrada é a negação da história judaica. De modo que os judeus devem deixar de ser judeus para serem reconhecidos como seres humanos iguais aos demais. ${ }^{23}$

Um ponto neste texto da década de 1930 digno de ênfase é a caracterização da típica postura política dos judeus face ao mundo, da qual Mendelssohn é representante. Essa crítica arendtiana já expressa a crítica à postura típica do filósofo em relação ao campo político. A atividade do pensar exige o isolamento e implica a indiferença diante dos eventos mundanos. ${ }^{24}$ "O homem pensante vive em absoluto isolamento; independente de todos os outros, ele encontra a verdade, que na realidade deveria ser comum a todos". (ARENDT, 2007, p. 7)

\footnotetext{
${ }^{18} \mathrm{O}$ artigo O Iluminismo e a questão judaica foi publicado em 1932, num período em que Arendt frequentava os círculos sionistas em Berlim.

${ }^{19}$ Comentando o texto, Jerome Kohn esclarece: "o termo "questão judaica" neste contexto se refere à problemática situação de um identificado povo que vive numa terra que não é sua terra, mas de um outro povo". (KOHN, 2007, p. $x v)$.

20 "A questão moderna judaica remonta ao Iluminismo; foi o iluminismo - isto é, o mundo não-judaico que a colocou. Suas formulações e suas respostas definiram o comportamento e a assimilação dos judeus". (ARENDT, 2007, p. 3).

${ }^{21}$ Segundo a interpretação de Arendt, Mendelssohn segue de perto Lessing. A distinção entre verdades da razão e verdades da história acarreta que as verdades históricas precisam passar pelo crivo da razão para serem aceitas. Essa distinção tem forte impacto nos campos da teologia e da religião, pois implica que é na autoridade da razão que se encontra o fundamento da religião. (Cf. ARENDT, 2007, p. 5)

${ }^{22}$ Interpretando o pensamento do judeu Mendelssohn, diz Arendt: "Somente "as verdades eternas" são independentes de toda a Escritura e apreendidas em todas as épocas; elas são a base da religião judaica, e é por causa delas que os judeus ainda estão ligados à religião de seus pais hoje”. (ARENDT, 2007, p. 7).

${ }^{23}$ Segundo Arendt os judeus seguidores de Mendelssohn "negaram sua própria história e consideraram tudo de particular em relação a eles como um impedimento para sua integração, para sua transformação em seres humanos plenos". (ARENDT, 2007, p. 9).

24 "Esta eliminação da realidade está intimamente ligada com a posição factual dos judeus no mundo. O mundo importa tão pouco para ele que se torna o epítome do que era inalterável. A nova liberdade da razão, da formação, do pensar por si próprio, não muda o mundo absolutamente. O judeu 'educado' continua a considerar o mundo histórico com a mesma indiferença sentida pelo judeu no gueto". (ARENDT, 2007, p. 8)
} 
Herder, na interpretação de Arendt, representa uma posição contrária à de Mendelssohn, pois não nega a história do povo judaico. Concebe a história como acontecimento irrevogável: o que foi feito no passado não pode ser desfeito no presente. No caso do judaísmo, não é possível negar que a história do povo judeu está dada e associada para sempre com Torá e a Lei. "Herder compreende a história dos judeus do mesmo modo como eles a interpretam, como a história do povo escolhido de Deus". (ARENDT, 2007, p. 12). Herder marca a diferença dos judeus em relação aos povos europeus - "um povo asiático estrangeiro em nosso continente" - mas a sua posição não é pro conservação dessa diferença definidora da identidade judaica, já que a incorporação dos judeus no modo de vida próprio dos povos alemães é vista como uma necessidade. Assim, apesar dos elementos positivos de sua posição ${ }^{25}$, no final das contas, Herder também despoja os judeus de sua história ${ }^{26}$, uma vez que a solução para a questão judaica proposta por ele é a incorporação ${ }^{27}$ dos judeus à cultura alemã.

A resposta assimilacionista é descartada para resolver a questão judaica. Para Arendt, o inegável fato da diferença histórica, religiosa e cultural dos judeus não faz deles diferentes em relação ao direito de habitar o mundo, de ser igual aos cidadãos de outras nações e de ser um povo livre. Para a existência livre do seu povo, Arendt defende o direito de ser igual e ser diferente dos judeus. A emancipação política judaica significa, portanto, "uma admissão dos Judeus enquanto judeus nas fileiras da humanidade". (ARENDT, 2007, p. 275). ${ }^{28}$

A diferença dos judeus, em relação aos outros povos, é patente no fato concreto de que o povo judeu é “o pária entre os povos do mundo". (ARENDT, 2007, p. 263). ${ }^{29}$ Arendt convoca os judeus a assumir essa condição de pária na luta política de sua emancipação, por isso, resgata, na história judaica, a atitude daqueles judeus que traduziram a condição de ser "pária consciente" no mundo. ${ }^{30}$ Ao retomar essa tradição

\footnotetext{
${ }^{25}$ Arendt reconhece que Herder resgata a história dos judeus: "Herder devolve aos judeus a sua história... a história é absolutamente levada a sério como aquilo que aconteceu". (ARENDT, 2007, p. 14).

26 “A compreensão de Herder da história os priva de seu passado. Mais uma vez eles ficam cara a cara com nada”. (ARENDT, 2007, p. 16).

27 A incorporação pressupõe a formação (educação) e a tolerância. "Dois conceitos caracterizam a humanidade: formação e tolerância". O pano de fundo da formação é o passado, "o poder dos precedentes". É preciso compreender os precedentes: aceitando-os como ocorreram, mas distanciando-se deles; a tolerância está neste distanciamento. (Cf. ARENDT, 2007, p. 13-4)

${ }^{28}$ Cf. "O judeu enquanto pária: uma tradição esquecida" Texto de 1944, republicado em The Jew as Pariah (1978); aqui seguimos a republicação em The Jewish Writings.

${ }^{29}$ Cf. "Uma via para a reconciliação dos povos", de 1942, publicado em The Jewish Writings.

30 “A história judaica moderna...é inclinada a esquecer outra linha da tradição judaica ... É a tradição de uma minoria de judeus que não quiseram se transformar em arrivistas, que preferiram o status de "pária consciente"... Sempre houve judeus que não pensaram que valesse a pena trocar sua atitude humana e sua
} 
esquecida, Arendt define os sentimentos párias fundamentais para os judeus lutarem pela sua liberdade: a rebeldia e a responsabilidade. ${ }^{31}$

A emancipação política, proposta por Arendt, envolve a "a emancipação nacional - isto é a Palestina". (ARENDT, 2007, p. 261). Arendt justifica a reivindicação de um território próprio para a nação judaica ${ }^{32}$ com base em dois princípios que considera essenciais para a política: "os conceitos em que toda a política se baseia são a liberdade e a justiça”. Para ela, a luta do povo judeu pelo seu território e pela sua liberdade funda-se no direito humano do judeu viver e se defender como judeu:

Um dos direitos inalienáveis dos judeus é o direito de viver e se preciso viver como um judeu. Um ser humano pode se defender somente na forma da pessoa em que é atacado. Para um judeu - num tempo em que seu povo é perseguido e a porção da terra deserta que ele tornou fértil pelo trabalho de suas mãos é ameaçada - isto significa lutar pela liberdade do seu povo e a segurança de sua terra.... Um povo que não mais defende a si próprio contra seus inimigos não é um povo mas um corpo vivo. (ARENDT, 2007, p. 261-2)

A partir do exposto acima, vê-se que Arendt defende uma solução política para a questão judaica e não uma solução social como propugnada pelo assimilacionismo. Para assimilar o judeu na sociedade europeia, o assimilacionismo exigia a perda da diferença judaica, e a exclusão da pluralidade entre os povos. Arendt proclama o direito dos judeus de ser iguais sem perder sua diferença. Igualdade de direitos para garantir a diferença de identidade cultural, no reconhecimento da pluralidade dos povos e no direito à liberdade. Para as tendências romântica e iluminista, os judeus precisam ser outro para se tornarem iguais, mas para Arendt a igualdade na sociedade não pode se dar às custas da perda da diferença. Posteriormente ao período destas reflexões, no processo de maturação de sua

percepção natural da realidade pela estreiteza do espírito de castas ou pela essencial irrealidade das transações financeiras". (ARENDT, 2007, p. 274).

${ }^{31}$ Para Arendt, foi Bernard Lazare que traduziu na política a condição pária do judeu: era contrário à "doutrina espúria" da assimilação, que exigia do judeu o abandono de suas características individuais e morais e era um rebelde que convocava os judeus para a ação política. "Ele demandava ao pária que... renunciasse à confortável proteção da natureza, e enfrentasse o mundo dos homens e das mulheres. Com outras palavras, queria que ele se sentisse responsável pelo que a sociedade tinha feito com ele... politicamente falando, cada pária que negava ser um rebelde era parcialmente responsável pela sua própria posição e com isso pela mancha na humanidade que isso representava. De tal vergonha não havia saída, nem na arte nem na natureza. Porque na medida em que um homem é mais do que uma mera criatura da natureza, mais do que um mero produto da divina criatividade, ele será chamado para explicar as coisas que os homens fazem com os homens no mundo em que eles próprios condicionam". (ARENDT, 2007, p. 285).

${ }^{32}$ A luta pela emancipação da nação judaica é defendida por Arendt segundo o princípio de que "não há nenhuma solução para os problemas nacionais sem um solo nacional”. (ARENDT, 2007, p. 261) 
filosofia política, Arendt definirá, em A Condição Humana, o conceito de pluralidade entrelaçando estas duas dimensões: a igualdade e a diferença.

A resposta à questão judaica não se resume na defesa da emancipação dos judeus. Arendt busca compreender numa ótica política as origens do ódio contra os judeus, raiz da negação do direito de eles serem livres.

\section{As origens do antissemitismo político.}

A defesa do direito de ser livre dos judeus e a luta pela realização desse direito não exaure a reflexão arendtiana sobre a questão judaica. Arendt procura compreender porque os judeus são odiados nas sociedades em que compartilham do mesmo solo com nações diferentes. Já no período do refúgio na França, tratou diretamente da temática do antissemitismo $^{33}$, mas não se debruçou sobre o ódio aos judeus de matiz religioso, o antissemitismo religioso, pois procurava desvendar o elemento propriamente político do antissemitismo a partir de sua origem.

Nessa primeira análise, entende que no período moderno a questão judaica foi ligada à defesa dos direitos humanos. ${ }^{34}$ Mas a associação das duas "causas" não foi benéfica para o povo judeu. Os iluministas não viam os judeus como um povo oprimido, mas como um símbolo universal ${ }^{35}$ da "libertação humana, do progresso e do abandono dos preconceitos”. (ARENDT, 2007, p. 62). Para eles, a solução para o problema judaico colocaria a humanidade numa nova era. O problema para Arendt estava nesta conversão do povo judaico num símbolo, de tal sorte que a luta emancipacionista não seria mais pela liberdade do judeu qua judeu, mas do ser humano abstrato, símbolo do sofrimento da opressão. Mais do que isso, para Arendt, foi com base nessa insuspeitada noção abstrata de judeu criada pelo iluminismo ${ }^{36}$ _ "o judeu em geral" - que os antissemitas formaram a ideia do princípio judaico, cujo significado é "uma aglomeração de características que

\footnotetext{
${ }^{33} \mathrm{O}$ manuscrito intitulado Antissemitismo foi escrito por volta de 1938 e 39 e publicado pela primeira vez em The Jewish Writings. Arendt concentra-se, sobretudo, no antissemitismo na Alemanha, "a terra clássica do antissemitismo". Esse material foi utilizado, posteriormente, em Antissemitismo, a primeira parte de Origens do Totalitarismo.

34 "Desde que o Iluminismo alemão colocou a equação teórica entre a causa dos judeus com a dos direitos humanos, e desde que a Revolução Francesa colocou esta ligação em prática, o padrão que nossa história seguiria foi irrevogavelmente traçado". (ARENDT, 2007, p. 63).

35 "Desde Lessing até Wilhelm von Humboldt, a questão Judaica e a emancipação Judaica foram equiparadas com a luta pela liberdade humana e a justiça universal". (ARENDT, 2007, p. 60).

36 "O modo clássico com que a questão judaica foi colocada no Iluminismo forneceu a base teórica do antissemitismo clássico”. (ARENDT, 2007, p. 64)
} 
são universalmente "más" e, embora observáveis em outros povos também, são sempre chamadas “judaicas”. (ARENDT, 2007, p. 64).

Mas além desta identificação do pressuposto iluminista na noção antissemita de judeu, Arendt ocupa-se dos elementos históricos e políticos do antissemitismo moderno. A narrativa arendtiana do surgimento e desenvolvimento do antissemitismo político trata da apoliticidade dos judeus. Historicamente, os judeus ricos financiaram o Estado e recebiam privilégios exclusivos em troca; ${ }^{37}$ havia um tipo de "aliança" entre os judeus ricos e o Estado. Os judeus detinham o poderio econômico, mas não gozavam de poder político por não pertencerem nem à classe da aristocracia nem da burguesia. Quando uma destas classes se opunha ao Estado, por efeito colateral opunha-se também aos judeus.

É nesse contexto de embate político das classes com o Estado que surge a ideologia antissemita, que propunha expurgar do corpo do estado, os elementos considerados nocivos em razão de sua origem. ${ }^{38}$

A descrição arendtiana da gênese do antissemitismo moderno revela que se trata de um fenômeno propriamente político, nascido do conflito de poder entre as classes na Alemanha, "a clássica terra do antissemitismo". (ARENDT, 2007, p. 60). Arendt mostra como, historicamente, os judeus tornaram-se marionetes nas mãos dos governantes e alvo indefeso dos grupos políticos. O que Arendt procura entender é porque os judeus não formaram um grupo com real poder político, uma vez que detinham o poderio econômico. Os judeus preferiam não se imiscuir na arena política de maneira ativa, confiando no sistema de proteção dado pelos governantes. Antes de assumir como natural essa postura judaica de fugir do agon político, Arendt coloca em questão as razões dessa postura, e daí produz suas primeiras reflexões sobre a ação política analisando o fenômeno de sua ausência.

\footnotetext{
37 "O judeu da corte num estado absolutista não podia ser roubado ou expulso. Seu crédito é tão bom quanto o dinheiro que ele, de fato, garante. E visto que seu crédito depende da sua pessoa, as finanças do estado são colocadas em perigo se ele não tiver direitos pessoais. Sua proteção não pode mais ficar a critério de cidades de principados menores. A questão judaica se torna uma questão de Estado. O judeu da corte é o judeu que protege o próprio Estado. O Estado garante a proteção pessoal de "seus" judeus, isto é, o crédito de seus judeus, assim como o judeu da corte é o garante das finanças e obrigações do Estado". (ARENDT, 2007, p. 80)

${ }^{38}$ Essa ideologia antissemita tem como origem a convergência do 'romantismo político' com o interesse da aristocracia prussiana. O lugar ocupado pelos judeus ricos no Estado era tido como ilegítimo porque pertencia, de direito, aos aristocratas, com base na sua hereditariedade. "As teorias românticas do Estado são o solo fértil de toda ideologia antissemita. Os judeus não têm nenhum lugar na "história orgânica". Somente a "arbitrariedade humana" - isto é, o curso atual da história - fez dos judeus, europeus. Eles alcançaram sua posição social, apesar de sua descendência por nascimento". (ARENDT, 2007, p. 99; grifo da autora).
} 


\section{Crítica à inação política dos judeus}

Arendt conclama os judeus à participação política, chamando-os a agirem no mundo. Esse chamado tem como pressuposto uma crítica à postura política dos judeus, que tange uma das questões centrais que perpassará toda a sua filosofia política: a questão da ação. As reflexões sobre a questão judaica não estão dissociadas do pensamento político ulterior de Arendt justamente porque nessas primeiras análises já é manifesto seu interesse de investigação da ação humana. Arendt se tornou uma filósofa da política uma teórica da política, como preferia ser chamada - partindo da questão judaica. A análise da questão judaica é uma introdução à filosofia política de Arendt, como sustenta Feldman. ${ }^{39}$

Como Arendt lida com a temática da ação política no início de sua filosofia política? Como já visto acima, Arendt despertou para a política quando começou a agir provocada pelo sentimento de responsabilidade diante das perseguições nazistas contra os judeus. Mas essa é apenas a dimensão prática do despertar político de Arendt. O que ocorre averiguar é a dimensão teórica decorrente de sua guinada para a política. Quando passa a se interessar pelo político, começa a lidar com a questão da ação. Contudo, nos seus estudos da questão judaica não busca elaborar uma concepção própria de política, mas de criticar a postura política dos judeus, que se tornou um obstáculo secular para a ação política deste povo. Assim, a ação política primeiramente é vista por Arendt sob o aspecto de inação ou apraxia. ${ }^{40}$

É preciso escavar a fundo as razões desse comportamento apolítico judaico. Arendt analisa, então, a autocompreensão que os judeus fazem do seu lugar na história e no mundo dos afazeres humanos. Se os judeus são inativos na política, é preciso indagar qual a origem desse tipo de atitude diante da realidade histórica. Assim o faz Arendt na consideração das interpretações da história judaica segundo as perspectivas que denomina

\footnotetext{
39 “Há um link essencial entre sua concepção da história judaica e sua teoria política: sua visão da condição judaica moderna serve como uma introdução para sua teoria política, enquanto que sua teoria política ilumina sua interpretação da história judaica". (FELDMAN, 2007, p. xlii)

${ }^{40}$ Arendt elaborou a noção de pária consciente para apresentar um tipo de rebelde que combate a opressão sofrida com base no direito de resistência dos povos. "É direito de todo ser humano resistir à opressão". Se o judeu não busca resistir à opressão a qual é submetido, então se torna responsável pela opressão que sofre. A postura dos judeus de não assumir a responsabilidade pela sua própria história teve consequências negativas para os próprios judeus. A apatia política não exime os judeus da responsabilidade política pelos acontecimentos que os atingem. Por não resistir aos opressores, tornaram-se paradoxalmente vítimas responsáveis pelo seu sofrimento. Arendt, que segue Lazare neste ponto, não responsabiliza os membros do seu povo pelo que eles fizeram, mas sim pelo que não fizeram, isto é, a crítica é direcionada à falta de iniciativa de agir.
} 
de assimilacionista e de nacionalista. Em ambas identifica a incapacidade de compreender o fenômeno do antissemitismo. ${ }^{41}$ Segundo Arendt, o ponto crítico é que a historiografia judaica não trata do fenômeno enquanto tal, não parte de sua gênese: "nunca faz a pergunta sobre o que torna o antissemitismo - e a crença nas acusações - possível... nunca indaga a respeito das condições reais que são a base para tais "calúnias e incompreensões". (ARENDT, 2007, p. 49)

Arendt reconhece o valor da crítica sionista à tendência assimilacionista. Contudo, segundo sua consideração, mesmo a crítica sionista não faz jus às reais condições que tornam o aparecimento do antissemitismo possível, pois parte de pressupostos que são puras abstrações, como a noção de que os povos são substâncias naturais. O sionismo cria conceitos abstratos para estabelecer uma relação de oposição entre o povo alemão nativo e a nação de estrangeiros, os judeus. No final das contas, diz Arendt, tanto o assimilacionismo quanto a crítica nacionalista dos sionistas adotam posições extremas. ${ }^{42}$

Em Antissemitismo ${ }^{43}$ Arendt continua tratando de teorias divergentes sobre a história judaica e o antissemitismo, como as doutrinas que denomina de "bode expiatório" 44 e de "antissemitismo eterno". ${ }^{45}$ Critica essas teorias porque eximem a

\footnotetext{
41 “Ambos os tipos de historiografia judaica são caracterizados por sua incapacidade de compreender o antissemitismo; ambos tentam reduzi-lo a opiniões individuais sobre os judeus. A historiografia nacionalista contenta-se simplesmente em examinar a história segundo as tendências amigáveis ou hostis para com os judeus, e após avaliar estas visões, reúne todas numa miscelânea. Os historiadores assimilacionistas, contudo, que tem a vantagem de pelo menos levar o antissemitismo a sério, embora somente nas suas formas mais inócuas, refuta as opiniões individuais - as incompreensões dos grandes homens e as mentiras dos homens menores - na crença de que é o melhor modo de contribuir para o progresso de nossa época". (ARENDT, 2007, p. 49)

${ }^{42}$ Uma tendência é extrema porque advoga a total fusão do povo judaico com o povo nativo e a outra porque propugna a total separação entre os judeus e os alemães. Na concepção do sionismo, os judeus formam um povo de natureza imutável, enquanto que, na outra ponta, a assimilação social significa a mudança total dos judeus, com a perda de sua identidade cultural. Os assimilacionistas acreditam ilusoriamente na identificação dos judeus com as nações que os recebem. Mas, para os sionistas os povos são entes substancias que se diferenciam um dos outros. Como o povo judeu é uma substância que sempre será a mesma, portanto não é possível sua fusão com outro povo. Para Arendt, no fundo, trata-se de duas formas ilusórias de compreender a história judaica.

${ }^{43}$ Nessa análise - que é a primeira parte de As origens do Totalitarismo e que incorpora o manuscrito Antissemitismo de The Jewish Writtings - o antissemitismo é compreendido como um dos elementos que com o imperialismo formam a estrutura do fenômeno do totalitarismo. Trata-se de uma análise histórica e política do antissemitismo (cf. AREDNT, 1973, p. 11), com o escopo de elucidar a passagem da questão judaica de um fenômeno insignificante a fenômeno de importância mundial. "Durante mais de cem anos o antissemitismo havia, lenta e gradualmente, penetrado em quase todas as camadas sociais em quase todos os países europeus, até emergir como a única questão que podia unir a opinião pública”. (ARENDT, 1973, p. 25/45, grifo nosso).

44 "Essa teoria defende a total inocência da vítima. Ela insinua não apenas que nenhum mal foi cometido, mas, também, que nada foi feito pela vítima que a relacionasse com o assunto em questão". (ARENDT, 1973, p. 5/25).

${ }^{45}$ Nessa teoria "o ódio aos judeus é apresentado como reação normal e natural, e que se manifesta com maior ou menor virulência segundo o desenrolar da história. Assim, as explosões do antissemitismo parecem não requerer explicação especial, como consequências "naturais" de um problema eterno".
} 
responsabilidade pela ação tanto dos nazistas quanto dos judeus. Essas teorias, segundo Arendt, conduzem à absolvição das vítimas e dos carrascos porque faz deles meros executores dos ditames eternos do destino histórico do povo judeu, isto é, a condenação eterna a ser vítima de expiação do mal no mundo. Nessas teorias, os judeus aparecem como vítimas inocentes, e os nazistas como executores igualmente inocentes, o bode expiatório de um lado, e o instrumento do natural e eterno ódio aos judeus, do outro. ${ }^{46}$

As doutrinas do "bode expiatório" e do "antissemitismo eterno" ao negarem a responsabilidade dos sujeitos envolvidos nos atos, ${ }^{47}$ eliminam toda e qualquer possibilidade da ação humana. Uma vez que o objetivo primordial do governo totalitário é aniquilar a liberdade humana, Arendt nota uma estranha convergência entre as doutrinas abraçadas pelos judeus e as práticas totalitárias: as doutrinas judaicas que forjam a autocompreensão do lugar dos judeus na história negam a possibilidade da ação enquanto que o governo totalitário e sua prática do terror eliminam a nascente da ação: a espontaneidade humana. Diz Arendt:

É deveras notável que as doutrinas que ao menos tentam explicar o significado político do movimento antissemita neguem qualquer responsabilidade específica da parte dos judeus e se recusem a discutir $\mathrm{o}$ assunto nestes termos. Ao implicitamente recusarem abordar o significado da conduta humana, assemelham-se às modernas práticas e formas de governo que, por meio do terror arbitrário, liquidam a própria possibilidade da ação humana”. (ARENDT, 1973, p. 8/28; grifo da autora).

A compreensão arendtiana da história judaica opõe-se à autocompreensão judaica expressa nestas doutrinas porque Arendt não nega a responsabilidade dos judeus pelos acontecimentos que acometeram o povo judaico. ${ }^{48}$ Como entender essa posição de Arendt

\footnotetext{
(ARENDT, 1973, p. 7/27). Segundo Arendt, essa teoria é adotada por antissemitas profissionais, historiadores imparciais e "até por um elevado número de judeus", que encontram no antissemitismo "um excelente meio de manter o povo unido, de sorte que na existência do antissemitismo 'eterno' estaria a eterna garantia da existência judaica”. (ARENDT, 1973, p. 7/27).

46 "De certa forma, nos campos de extermínio nazistas os judeus eram assassinados de acordo com a explicação oferecida por essas doutrinas à razão do ódio: independentemente do que haviam feito ou deixado de fazer, independentemente de vício ou virtude pessoais. Além disso, os próprios assassinos, apenas seguindo ordens e orgulhosos de sua desapaixonada eficiência, assemelhavam-se sinistramente aos instrumentos "inocentes" de um ciclo inumano e impessoal de eventos, exatamente como os considerava a doutrina do eterno antissemitismo". (ARENDT, 1973, p. 8/28)

47 Para Arendt, as ideologias que pretendem ser as "chaves da história" são, na verdade, "desesperados esforços de fugir à responsabilidade”. (ARENDT, 1973, p. 9/29)

${ }^{48}$ Segundo Feldman (p. xlvi) a crítica de Arendt à história de passividade política dos judeus reflete "sua convicção política fundamental de que o mundo é o que nós fazemos dele", assim os judeus são responsáveis pelo que acontece ou não acontece na sua história, já que essa não é inevitável nem acidental, mas "o resultado da história específica das relações dos judeus com os gentios. " Para Feldman, a chave de
} 
em relação à responsabilidade de judeus? À luz da narrativa arendtiana da história do antissemitismo moderno, importa salientar que a responsabilidade dos judeus se refere à omissão histórica deles, que se negaram a assumir uma posição política, escolhendo retrair-se no isolamento do gueto, distanciando-se do mundo das relações humanas e fazendo alianças 'políticas' de conveniência com os governantes. Por conseguinte, a responsabilidade política dos judeus refere-se à ausência de ação, de envolvimento prático no mundo dos assuntos humanos, evitando qualquer forma de inserção no campo político.

A compreensão arendtiana da história judaica é uma contraposição às doutrinas deterministas já mencionadas. É uma compreensão histórica que difere dessas teorias por ser anticonformista. Arendt expõe os fatos, ilumina-os explicando seu sentido, mas não se conforma a eles. Não cai no equívoco fatalista de se render aos fatos com a justificativa de que os fatos ocorridos não poderiam ter acontecido de maneira diferente. Arendt busca revelar como e porque os fatos aconteceram, enfatizando que poderiam ter acontecido diferentemente e desvelando a dimensão da contingência na história. Assim a sua análise antideterminista da história judaica se distancia das perspectivas deterministas das assim chamadas doutrinas do "bode expiatório" e do "antissemitismo eterno", que concebem os judeus como as vítimas eternas dos carrascos gentios. Essas doutrinas convergem para o mesmo ponto: transformar em necessidade e lei histórica o recorrente sacrifício dos judeus na história.

Para diferenciar a sua compreensão das interpretações que concebem a história judaica e os dramáticos eventos de destruição do povo judaico como inevitáveis, Arendt revela que compreende a história como realidade humana marcada pela contingência, abrindo assim o espaço para a resistência diante dos acontecimentos:

Repito: compreender não significa negar o ultrajante, subtrair o inaudito do que têm precedentes, ou explicar fenômenos por meio de analogias e generalidades tais que se deixa de sentir o impacto da realidade e o choque da experiência. Significa antes examinar e suportar conscientemente o fardo que os eventos colocaram sobre nós - sem negar sua existência nem vergar humildemente a seu peso, como se tudo o que de fato aconteceu não pudesse ter acontecido de outra forma. Compreender significa, em suma, encarar a realidade, espontânea e atentamente, e resistir a ela - qualquer que seja, venha a ser ou possa ter sido. (ARENDT, 1973, p. xiv/21, grifo nosso). ${ }^{49}$

leitura para compreender a ausência de ação política dos judeus na modernidade é a worldlessness (lit. ausência de mundaneidade) dos judeus.

49 Esta citação é extraída do Prefácio à Antissemitismo, inserido na $3^{\text {a }}$ edição de Origens do Totalitarismo, de 1967 (cf. ARENDT, 1973, p. 21) que retoma com alterações e acréscimos a definição do papel da compreensão filosófica que aparece no Prefácio à $1^{\text {a }}$ edição de 1950 (cf. ARENDT, 1973, p. 12). Além da 
A interpretação antideterminista dos eventos que atingiram o povo judeu caracteriza sua compreensão da história como constituída pela ação humana no mundo. Por essa razão, sua crítica às teorias do "bode expiatório" e do "eterno antissemitismo" acusa a ausência da iniciativa da ação, deslocando o poder de agir para forças diferentes ao ser humano, que definem o rumo dos acontecimentos da história humana.

Para Arendt não se trata apenas de ir aos acontecimentos e explicar como eles ocorreram, mas de resistir a eles sem abraçar explicações que atenuam o peso e a gravidade dos fenômenos. Além disso, a compreensão arendtiana dos eventos ressalta que esses poderiam não ocorrer do modo que ocorreram. Os eventos históricos são contingentes. A contingência dos eventos decorre da ação humana. Assim, afirmar que a compreensão arendtiana é política significa dizer que sua interpretação desvela a possibilidade da ação a partir da crítica às teorias e práticas que anulam essa possibilidade.

Segundo o juízo de Arendt, a história moderna dos judeus testemunha a ausência de ação política. ${ }^{50} \mathrm{O}$ seu esforço interpretativo concentra-se em elucidar porque os judeus não atualizaram o potencial de ação, tornando a liberdade uma realidade mundana. Pelo contrário, os judeus se retraíram e seguiram um caminho de isolamento e alienação em relação ao âmbito dos assuntos públicos.

$\mathrm{Na}$ tentativa de compreensão do antissemitismo, Arendt não apenas mostra o conflito político de fundo que engendrou o antissemitismo moderno, mas também estabelece a relação entre a expansão do ódio aos judeus com a retração de ação política dos próprios judeus.

Arendt se opõe às interpretações judaicas do antissemitismo porque em nenhuma delas a questão da ação política é colocada. Essas interpretações não mobilizam para a ação, mas aceitam com resignação e passividade as perseguições, como se fossem eventos inevitáveis. Para Arendt, ao contrário, compreender é resistir. A condição de

\footnotetext{
alteração de "o fardo que nosso século" por "o fardo que os eventos", no Prefácio de 1967 é acrescido: "como se tudo que de fato aconteceu não pudesse ter acontecido de outro modo" e "possa ter sido". Restando claro que em 1967 Arendt buscou enfatizar a contingência dos fatos, reforçando ainda mais a sua posição antinecessitarista da história.

${ }^{50}$ Para Arendt, o seu povo possui desde o início uma clara concepção da história, e do seu lugar no plano da história enquanto povo escolhido por Deus, mas que "evitou qualquer ação política durante 2 mil anos"; a realidade vivida pelos judeus após a Diáspora, um povo sem território, é chamada em causa, em parte, para explicar a indiferença política dos judeus: "É preciso lembrar também que a inabilidade de análise política resultava da própria natureza da história judaica, história de um povo sem governo, sem país e sem idioma". (ARENDT, 1973, p. 8/28).
} 
possibilidade de resistência política é desvelada na interpretação que Arendt faz da história judaica.

Em nenhum momento da sua análise, Arendt minimiza a história de calamidades e sofrimentos dos judeus, mas contrapõe-se à maneira como é narrada pelas doutrinas fatalistas, que escamoteiam a história da recusa a agir. Não há lugar para a ação nessas doutrinas porque negam a contingência da história em nome da necessidade. A contingência da história radica-se na possibilidade da ação humana; não fossem os seres humanos capazes de agir, a história seria o eterno ciclo do mesmo ou a mecânica execução de leis, divinas ou naturais, que regulam a ocorrência dos fatos.

A crítica à historiografia judaica é parte da crítica à apraxia e inação judaicas. Os judeus foram vítimas, de fato, mas poderiam ter tomado iniciativas para resistir à violência contra eles. Não há um decreto eterno de condenação contra os judeus. As injustiças que sofreram poderiam ter sido combatidas por meio de reações no plano político. Arendt está dizendo que uma vez que os judeus não agiram politicamente, a tendência da historiografia judaica é buscar encontrar justificativas para o comportamento apolítico dos judeus. Como Arendt não compartilha dessa solução apologética para o comportamento dos judeus, segue outra perspectiva, buscando compreender porque os judeus não agiram politicamente.

Embora Arendt afirme que "a história judaica oferece extraordinário espetáculo de um povo que ... evitou qualquer ação política durante 2 mil anos” (ARENDT, 1973, p. 8/28), não falta, nos seus escritos, referência a determinados episódios históricos em que os judeus agiram. Arendt busca resgatar a experiência da ação política dos judeus. Esse resgate é essencial porque evidencia que, de fato, houve a atualização da capacidade de ação pelo povo judeu. Tanto era possível aos judeus agirem que, de fato, agiram.

Em A história judaica revisada ${ }^{51}$, Arendt critica a historiografia judaica pelo silêncio em relação aos movimentos do passado em que os judeus decidiram assumir a condução de sua própria história ${ }^{52}$, e por evitar tratar da relação do pensamento místico com a ação política, no caso específico do movimento sabatista. ${ }^{53}$

\footnotetext{
${ }^{51} \mathrm{O}$ artigo A história judaica revisada foi publicado em 1948, posteriormente saiu na coletânea The Jew as Pariah, 1978. Aqui sigo a publicação contida em The Jewish Writings.

52 A historiografia judaica do séc. XIX, segundo Arendt, ignora as inciativas políticas da história judaica, afirmando que os judeus "não tiveram uma história política própria, mas foram invariavelmente as vítimas inocentes de um ambiente hostil e, por vezes, brutal". (ARENDT, 2007, p. 303).

${ }^{53}$ Interessa para Arendt indicar que nesse evento, o pensamento místico conduziu seus seguidores para a ação, rompendo com a mera interpretação da lei e com a simples esperança na vinda do Messias. O resgate político desse movimento judaico por parte de Arendt foi possível devido ao trabalho de Gershon Scholem sobre o misticismo judaico - Major Trends in Jewish Mysticism - que "não apenas preenche uma lacuna,
} 
O resgate desta história não é uma narrativa da história dos vencedores, já que o movimento falhou e a derrota do movimento trouxe profundas consequências para o povo judeu, sobretudo porque rompeu com sua principal fonte de mobilização para ação: a esperança messiânica. ${ }^{54}$ Contudo, esse resgate histórico revela que a visão antideterminista e contingente da história defendida por Arendt conta com o dado da experiência histórica do seu povo. Antes de ser uma contraprova da posição de Arendt, para quem "os judeus não tinham qualquer tradição ou experiência política" (ARENDT, 1973, p. 43), esse exemplo histórico resgatado por ela dá mostras de que a possibilidade de ação política era real, e que a história política dos judeus poderia ter sido outra, que era possível ter iniciado novos processos históricos, já que é nessa possibilidade trazida ao mundo por cada ser humano que toda ação política se enraíza.

\section{Conclusão}

A formação filosófica de Arendt veio do estudo da tradição da filosofia alemã e do debate contínuo com seus mestres: Heidegger e Jaspers. Mesmo com essa formação na sua bagagem, Arendt faz uma guinada para a filosofia política, rompendo com sua formação original. O início dessa reviravolta foi provocado por uma questão de cunho pessoal. O primeiro passo rumo à política Arendt o deu devido a sua condição de judia. Arendt sentiu-se responsável por fazer alguma coisa para resistir contra a perseguição nazista ao seu povo, passando a agir em colaboração com os movimentos de resistência. Após esse primeiro passo para a política, começa a 'pensar' a política, concentrando-se

mas na realidade muda o inteiro cenário da história judaica”. (ARENDT, 2007, p. 303). O movimento sabatista foi um movimento singular: "nunca antes um grande movimento popular e uma ação política imediata tinham sido inspirados, preparados e direcionados por nada mais do que a mobilização das especulações místicas”. (ARENDT, 2007, p. 310).

54 Arendt expressa sua avaliação do movimento em O Estado Judeu (texto de 1945, republicado em The Jew as a Pariah e em The Jewish Writings): “...o movimento de Shabettai Tzevi, o movimento místicopolítico pela salvação dos judeus encerrou a Idade Média judaica e acarretou uma catástrofe cujas consequências determinaram as atitudes judaicas e suas convicções básicas por mais de dois séculos posteriormente. Em preparando-se para seguir Shabbetai Tzevi, o autodenominado "Messias", de volta para a Palestina em meados do século XVII, os judeus presumiram que sua esperança definitiva num milênio messiânico estava para se realizar. Até o tempo de Shabbetai Tzevi, eles foram capazes de conduzir seus negócios comuns por meios políticos que existiam no plano da imaginação sozinha - a memória de um passado e a esperança de um futuro distantes. Com o movimento de Shabettai Tzevi estas memórias centenárias e esperanças culminaram num intensificado movimento singular. Sua catastrófica consequência trouxe o fim - provavelmente para sempre - do período em que a religião sozinha podia fornecer aos judeus uma estrutura estável para satisfazer suas necessidades quotidianas, políticas e espirituais". (ARENDT, 2007, p. 378). 
nas questões políticas ligadas à situação do povo judaico. Suas primeiras reflexões se referem à "questão judaica".

As primeiras reflexões de Arendt sobre a política judaica trazem em seu bojo questões que mais tarde seriam tematizadas por ela na maturação de sua filosofia política. Essas questões, como vistas, tangem tópicos fundamentais do pensamento arendtiano: a pluralidade, a ação e a interpretação não determinista da história. A pluralidade desponta nas primeiras reflexões políticas porque a defesa que Arendt faz da emancipação judaica é calcada no princípio de que os judeus têm o direito de viver como judeus. Pluralidade diz respeito a igualdade e a diferença. Os judeus por serem iguais politicamente podem viver sua diferença cultural e religiosa, fazendo parte da pluralidade humana, defende Arendt contra as ideologias que cobravam a perda da identidade como preço pago para ter igualdade. A crítica de Arendt à apraxia dos judeus já contem in nuce aspectos de sua teoria da ação e de sua crítica às ideologias e filosofias da história que eliminam a contingência dos fatos históricos ao assumir uma lei, um agente ou um motor que determina o curso dos acontecimentos fazendo do ser humano uma marionete no palco da necessidade.

\section{Referências}

ARENDT, Hannah. The Origins of Totalitarianism. San Diego, New York: Harcourt Brace and Company, 1973. (Origens do Totalitarismo. Tradução Roberto Raposo. São Paulo: Companhia das Letras, 1989.).

The Life of the Mind. New York: Harvest Book, Harcourt, Inc., 1978. (A Vida do Espírito. 3 ed. Rio de Janeiro, Relume-Dumará, 1995).

Essays in Understanding (1930 - 1954). New York: Harcourt Brace and Company, 1994. (Compreender: formação, exílio e totalitarismo. Belo Horizonte: Editora UFMG, 2008).

1992.

Correspondence with Karl Jaspers, 1926-1969. New York: Harcout Brace,

The Jewish Writings. New York: Schocken Books, 2007.

On Arendt. In: HILL, M. The Recovery of the Public World. New York: St. Martin's Press, 1979

BERNSTEIN, Richard. Hannah Arendt and the Jewish Question. Cambridge/Massachussets: MIT Press, 1996. 
FELDMAN, Ron H. Introduction. The Jew as Pariah: The Case of Hannah Arendt (19061975). In: ARENDT, H. The Jewish Writings. New York: Schocken Books, 2007.

HILL, M. The Recovery of the Public World. New York: St. Martin's Press, 1979.

KOHN, J. Preface. A Jewish Life: 1906-1975. In: ARENDT, H. The Jewish Writings.

New York: Schocken Books, 2007 